TurtleLog:

Online Newsletter of the IUCN/SSC Tortoise and Freshwater Turtle Specialist Group

International Union for Conservation of Nature / Species Survival Commission

ISSN 1947-7635 (online) • www.iucn-tftsg.org/turtlelog_online_newsletter/

TurtleLog Number 3 •Published 24 May 2009・doi:10.3854/tln.003.2009

\title{
Illegal Domestic Trade of the Philippine Forest Turtle (Siebenrockiella leytensis) in the Philippines
}

\author{
Pierre Fidenci ${ }^{1}$ and Jérôme Maran ${ }^{2}$ \\ ${ }^{1}$ Endangered Species International, 79 Brady St., San Francisco, California 94113 USA \\ [pfidenci@endangeredspeciesinternational.org]; \\ ${ }^{2}$ L'Association du Refuge des Tortues, 26 place du Souvenir, 31660 Bessières, France \\ [jerome.maran@wanadoo.fr]
}

The critically endangered Philippine forest turtle, Siebenrockiella (Panayenemys) leytensis, is endemic to the Philippines, occurring only on one major island, Palawan, and its small satellite island, Dumaran (Diesmos et al. 2008). The Philippine forest turtle is one of the most endangered turtle species in the world (Turtle Conservation Fund 2003; IUCN 2008) with a rather limited natural distribution. Main threats to the Philippine forest turtle include over-collecting for illegal trade and habitat loss and degradation (Diesmos et al. 2008). The species is nationally protected by the Philippines Wildlife Act as well as by listing on CITES Appendix II (Diesmos et al. 2008).

First described by Taylor (1920) and previously erroneously thought to occur on Leyte Island, the Philippine forest turtle was considered enigmatic and thought extremely rare (IUCN/SSC Tortoise and Freshwater Turtle Specialist Group and Asian Turtle Trade Working Group 2000) until live specimens were observed for the first time in situ in 2001 and 2003 in northern Palawan, Philippines (Diesmos et al. 2003; Fidenci 2004).

We conducted ongoing monitoring at markets known to sell pets and wild animals in Manila between 10 March 2005 and 4 April 2009, totaling 32 visits. Monitoring activities were conducted using undercover methods and photos of turtles sold illegally were taken when possible.

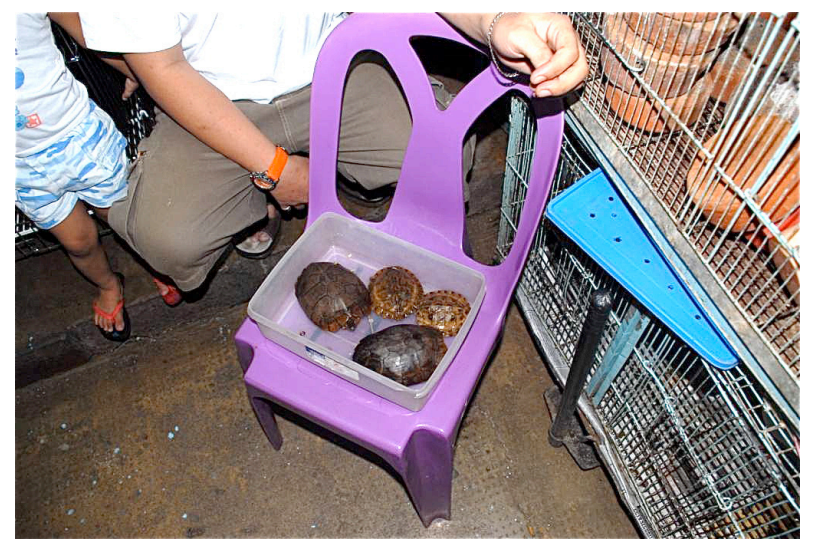

During this time period, we continuously observed $S$. leytensis in all major pet markets in Manila (e.g., Cartimar), including the main Chinese market, demonstrating that the domestic illegal trade remains rampant and has not decreased over the years. Our findings differ from those of Matillano (2008) who stated that "S. leytensis no longer exists at least in Manila, the main trans-shipment point of trafficked wildlife. Visits in Manila pet markets... found no presence of S. leytensis." His lack of finding $S$. leytensis may have been due to use of less clandestine methods to locate animals in various markets.

During our visits, we observed between two and ten S. leytensis for sale at each market, observing 171 animals over the 4-year period. The turtles were not sold openly as they were prior to 2005 ; instead, they were kept hidden in the back of stores and brought to potential buyers only when it was felt that there were no risks involved. Pet stores called the species "Palawan turtle" or simply "leytensis". During our last 2009 surveys, the species was sold for between 2500 and 3500 pesos (53 and 75 USD) per turtle, but could be negotiated down to 1200 pesos (28 USD) for smaller individuals. In general, turtles were cheaper at the Chinese market. This was a 4- to 6-fold price increase since 2005. Our undercover monitoring methods revealed that turtles could be ordered within one or two weeks but that large-sized turtles were dif-

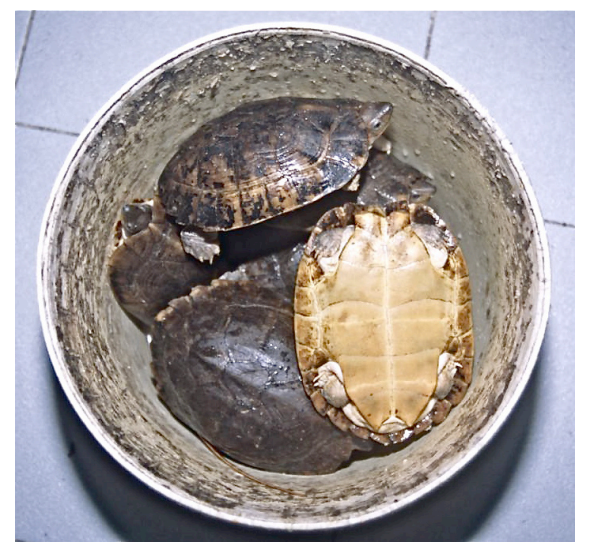

Figure 1. Siebenrockiella leytensis illegally sold at a domestic pet market in Manila, March 2009. Photos by Pierre Fidenci (left) and Jérôme Maran (right). 

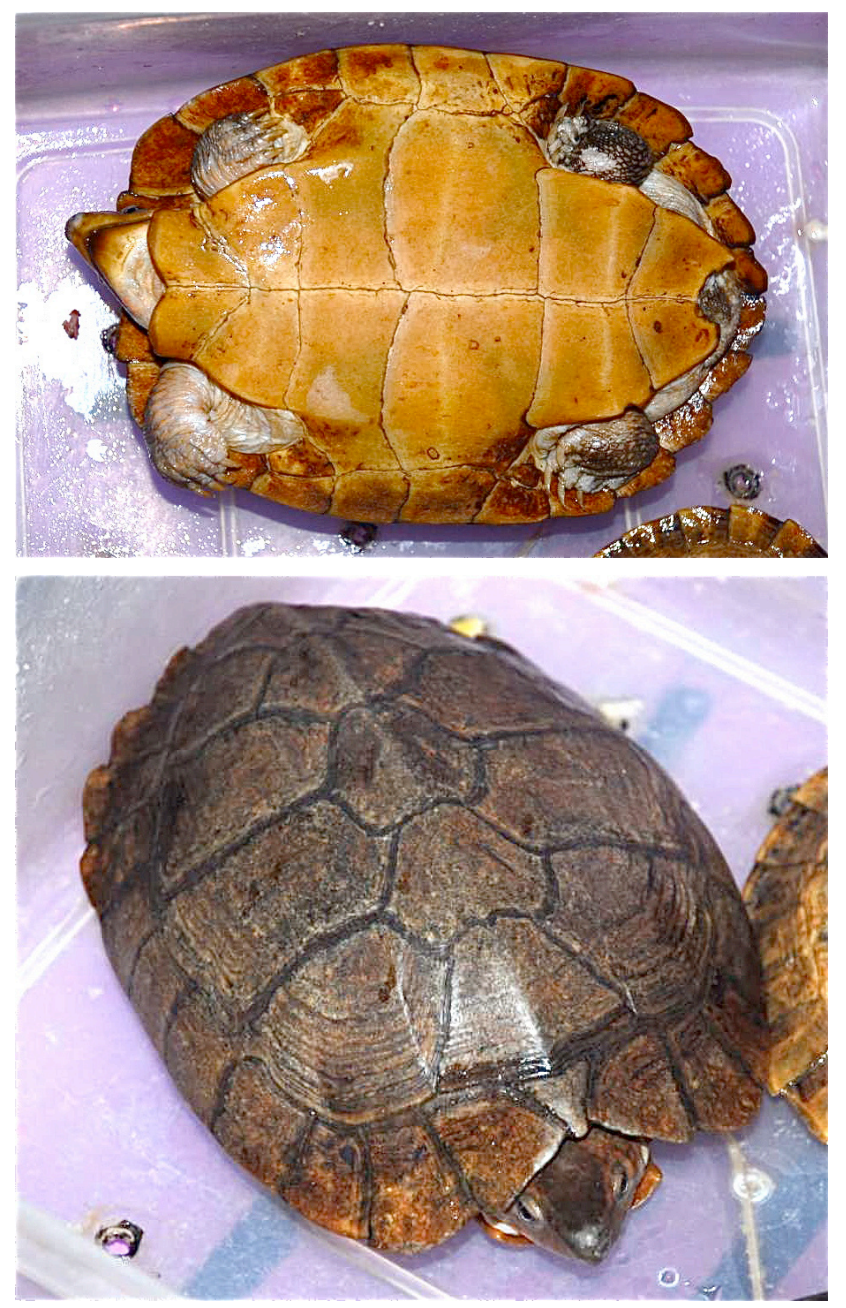

Figure 2. Siebenrockiella leytensis illegally sold at a domestic pet market in Manila, March 2009. Photos by Pierre Fidenci.

ficult to obtain. Most of the turtles sold for the domestic pet trade were sub-adults and young adults. It was rather uncommon to find large individuals (greater than $30 \mathrm{~cm}$ in carapace length) for sale.

Overall, illegal collecting of the Philippine forest turtle is the most prominent factor contributing to the decline of the species. Our multiple visits demonstrate that the illegal domestic trade of S. leytensis has never slowed down and continues to deplete remaining wild populations in Palawan.

Like most turtles, S. leytensis appears to have a long life span, delayed sexual maturity, iteroparity, and high adult survival rates (though ecological studies are only now beginning to elucidate these life history characteristics). Particular attention should be paid to evidence of skewed age structures or other indications of population sinks indicating long term impacts to populations with limited recovery capabilities due to illegal overharvesting.

Despite international and national laws designed to prevent exploitation of the critically endangered Philippine forest turtle, this species has been sold illegally for domestic and international trade for almost eight years now. Trade is still rampant and the species is being sold in the Philippines, North America, Europe, and Japan (Diesmos et al. 2008 and this report).

The ongoing level of trade highlights the failure of past and current activities to stop or reduce illegal trade, in particular at the domestic level. Based on the current threats, we recommend that the following measures be undertaken:

- Target known illegal traders in Palawan. Some have been known for a while now, but no legal actions have yet been undertaken by local authorities or other concerned organizations.

- Develop active partnerships at all levels between all concerned parties to work together to close down the trade.

- Provide immediate effective in situ long-term protection of current wild populations and their habitats, including associated benefits to local communities.

- Increase awareness of the illegal trade and status of the Philippine forest turtle within the range of the species.

- Research activities should address long term impacts to populations with limited recovery capabilities due to illegal overharvesting, such as evidence of skewed population age structures or other indications of stress and unsustainable harvesting.

Acknowledgments. - We would like to thank the Conservation Leadership Programme (formerly BPConservation Programme), Turtle Conservation Fund (TCF), Turtle Survival Alliance (TSA), British Chelonia Group (BCG), Sophie Danforth Conservation Biology Fund, Future for Wildlife Program, and Endangered Species International (ESI) for support during these studies.

\section{Literature Cited}

Diesmos, A.C., Gee, G.V.A., Diesmos, M.L., Brown, R.M., Widmann, P.J., and Dimalibot, J.C. 2004. Rediscovery of the Philippine forest turtle, Heosemys leytensis (Chelonia: Bataguridae), from Palawan Island, Philippines. Asiatic Herpetological Research 10: 22-27.

Diesmos, A.C, Brown, R.M, Alcala A.C, and Sison R.V. 2008. Status and Distribution of Nonmarine Turtles of the Philippines. Chelonian Conservation and Biology 7(2):157-177.

Fidenci, P. 2004. Discovery of a wild population of the critically endangered Philippine forest turtle, Heosemys leytensis, in Palawan, Philippines. Turtle and Tortoise Newsletter.8:1-2.

IUCN. 2008. The 2008 IUCN Red List of Threatened Species. Gland: IUCN. http://www.redlist.org.

IUCN/SSC Tortoise and Freshwater Turtle Specialist Group and Asian Turtle Trade Working Group. 2000. Recommended changes to 1996 IUCN Red List status of Asian turtle species. In: van Dijk,P.P., Stuart, B.L., and Rhodin, A.G.J.(Eds.).Asian Turtle Trade: Proceedings of a Workshop on Conservation and Trade of Freshwater Turtles and Tortoises in Asia. Chelonian Research Monographs No. 2, pp. 156-164.

Matillano, J.D. 2008. Status and Dynamics of Trade of Heosemys leytensis. CEPF Small Grant, Final Project Completion Report. 
Taylor, E.H. 1920. Philippine turtles. Philippine J. Science 16:130-133.

Turtle Conservation Fund. 2003. Top 25 Turtles on Death Row: new list spotlights most endangered turtles and action plan to save them. Conservation International, Press Release 15 May 2003, http://www.turtleconservationfund.org/top-25/.

\section{Citation Format for this Publication:}

Fidenci, P. And Maran, J. 2009. Illegal domestic trade of the Philippine forest turtle (Siebenrockiella leytensis) in the Philippines. TurtleLog No. 3, doi:10.3854/tln.003.2009, http:// www.iucn-tftsg.org/turtlelog_online_newsletter/tln003/. 